\title{
Gold-hosting supracrustal rocks on Storø, southern West Greenland: lithologies and geological environment
}

\author{
Christian Knudsen, Jeroen A.M. van Gool, Claus Østergaard, Julie A. Hollis, \\ Matilde Rink-Jørgensen, Mac Persson and Kristoffer Szilas
}

A gold prospect on central Storø in the Nuuk region of southern West Greenland is hosted by a sequence of intensely deformed, amphibolite facies supracrustal rocks of late Mesoto Neoarchaean age. The prospect is at present being explored by the Greenlandic mining company NunaMinerals A/S. Amphibolites likely to be derived from basaltic volcanic rocks dominate, and ultrabasic to intermediate rocks are also interpreted to be derived from volcanic rocks. The sequence also contains metasedimentary rocks including quartzites and cordierite-, sillimanite-, garnet- and biotite-bearing aluminous gneisses. The metasediments contain detrital zircon from different sources indicating a maximum age of the mineralisation of c. $2.8 \mathrm{Ga}$. The original deposition of the various rock types is believed to have taken place in a back-arc setting. Gold is mainly hosted in garnet- and biotite-rich zones in amphibolites often associated with quartz veins. Gold has been found within garnets indicating that the mineralisation is pre-metamorphic, which points to a minimum age of the mineralisation of $c .2 .6 \mathrm{Ga}$. The geochemistry of the goldbearing zones indicates that the initial gold mineralisation is tied to fluid-induced sericitisation of a basic volcanic protolith. The hosting rocks and the mineralisation are affected by several generations of folding.

\section{Regional geology}

The Nuuk region is renowned for the presence of rocks representing at least three major episodes of crustal accretion during the first billion years of the Earth's history. Each episode is characterised by early formation of supracrustal rocks followed by intrusion of tonalites now occurring as grey hornblende-biotite gneisses. The rock packages have subsequently been deformed and metamorphosed, resulting in often very complex outcrop patterns. Hollis et al. (2006) outlined the following sequence of events. The Eoarchaean Isua supracrustal belt $(3.87-3.71 \mathrm{Ga})$ is cut by 3.85 to $3.65 \mathrm{Ga}$ tonalites deformed and metamorphosed at $c .3 .65 \mathrm{Ga}$. The next sequence of supracrustal rocks was formed at $c .3 .1-3.07$ Ga, intruded by tonalites at $c .3 .07-3.05 \mathrm{Ga}$, and deformed and metamorphosed at $c .2 .98 \mathrm{Ga}$. The supracrustals linked to the third episode were formed at c. 2.85 to $2.8 \mathrm{Ga}$, intruded by tonalites at $c .2 .83$ to $2.75 \mathrm{Ga}$, and deformed and metamorphosed at 2.7 to $2.6 \mathrm{Ga}$. The last major event in the region was the intrusion of the Qorqut Granite at c. $2.53 \mathrm{Ga}$. The rocks formed during these episodes crop out in a complex pattern of blocks or terranes often only a few tens of kilometres wide. Attempts have been made to map and name these terranes (e.g. Nutman et al. 2004; Friend \& Nutman 2005), but as the rock types belonging to the different episodes are very similar, it has proved to be very difficult to distinguish and map the terranes in the field (Hollis et al. 2006).

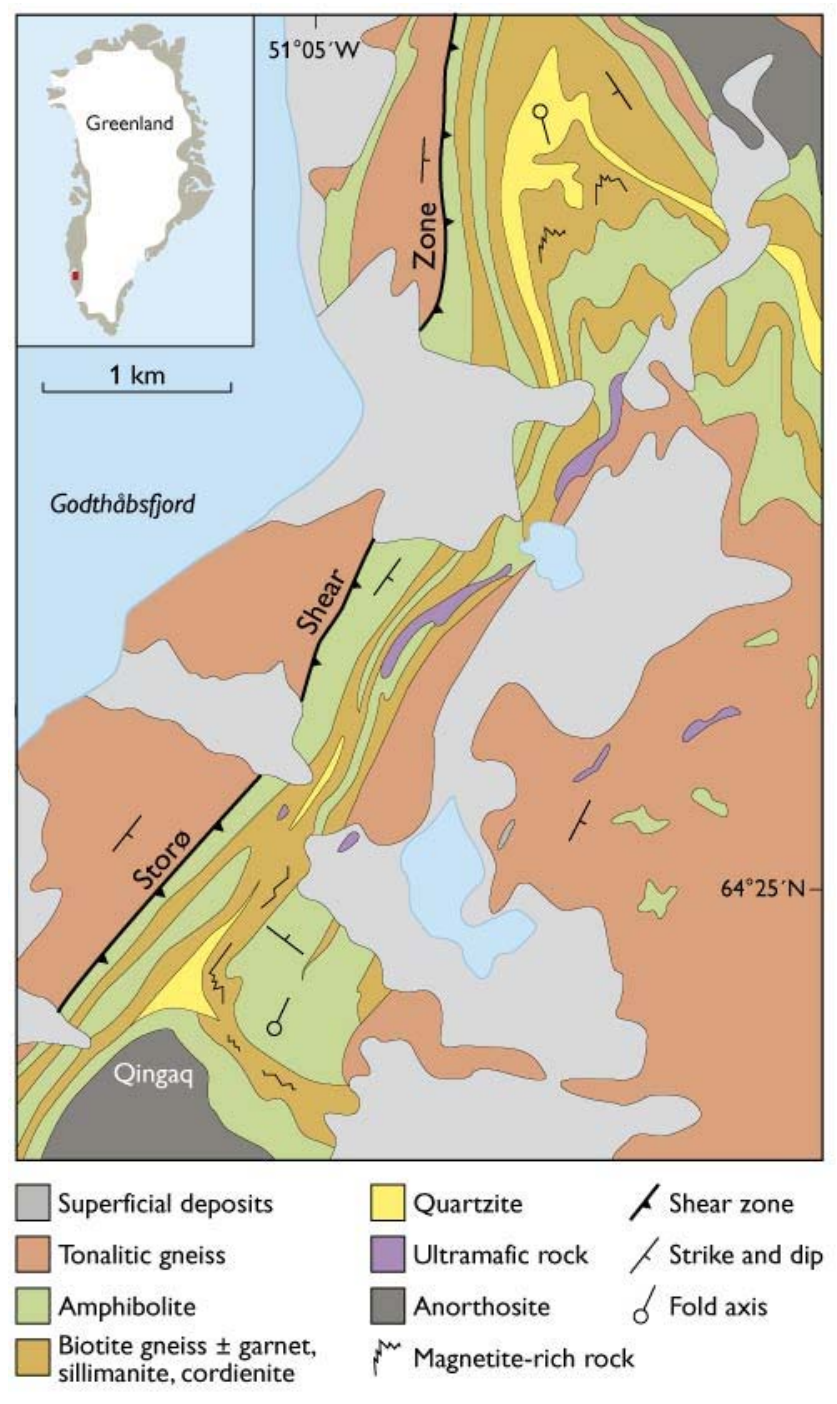

Fig. 1. Map of supracrustal units in the central part of Storø. The supracrustal rocks are cut by numerous pegmatites not shown on this map. 


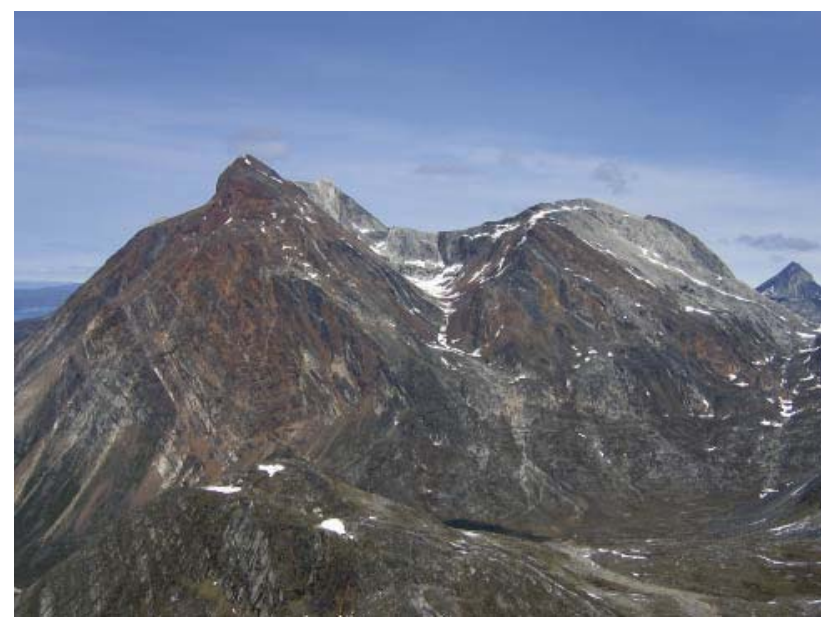

Fig. 2. View of the Storø supracrustal units looking north-east from Qingaq. To the left, the south-west-dipping Storø shear zone is visible. The rusty weathering rocks are supracrustals mainly thought to be of metasedimentary origin. The amphibolites are dark grey and the anorthosite body light grey. Highest summit at left is $1425 \mathrm{~m}$.

The gold-hosting supracrustal sequence overlies the Storø shear zone (Figs 1, 2), an oblique ductile thrust which juxtaposes the supracrustal sequence against the $c .3050 \mathrm{Ma}$ tonalitic Nûk gneisses to the west. The gneisses to the south-east are thought to be Palaeoarchaean tonalites. The thrusting along the Storø shear zone occurred syn-to-post the latest folding event and is broadly coeval with a phase of pervasive intrusion by pegmatites at $2630 \mathrm{Ma}$.

\section{Lithologies}

The supracrustal rocks on Storø comprise a range of lithologies including quartzites, quartzo-feldspathic gneisses, aluminous schists and gneisses, amphibolites and ultramafic rocks. The distribution and relative abundance of rocks in the central part of the island is shown in Fig. 1. The rocks are metamorphosed to amphibolite facies, and the dominant lithology is mafic amphibolite.

The amphibolites (mafic, foliated, amphibole-dominated rocks) can be divided into a number of types. They are all highly strained while compositional layering varies from subtle variations on $\mathrm{dm}$ - to $\mathrm{m}$-scale in dark amphibolite, to more distinct $\mathrm{cm}$-scale compositional layering in more leucocratic amphibolites. The most common type is homogeneous amphibolite, a medium- to coarse-grained, black to dark grey rock mainly composed of hornblende and plagioclase. The proportion of plagioclase to hornblende varies, and minor amounts of quartz, biotite, sphene, apatite and ilmenite occur. Locally, near some large anorthosite bodies at the structural base of the sequence, the hornblende or the plagioclase in the amphibolite occurs as $\mathrm{cm}$-sized aggregates, suggesting that the amphibolite here may represent metamorphosed gabbroic rock. Varieties of the homogeneous amphibolites include garnet amphibolites and diopside amphibolites.

Several types and generations of quartz veins have been observed in the amphibolites. These include (1) 1-2 cm thick sheeted quartz veins, with sharp contacts to the host rocks, concordant and generally isoclinally folded; (2) thin, spidery quartz veins anastomosing through the rocks; (3) centimetre to decimetre thick agmatitic quartzo-feldspathic veins that anastomose within $0.5-2 \mathrm{~m}$ wide zones; and (4) generally concordant quartzo-feldspathic veins, commonly with minor garnet.

A suite of foliated felsic and aluminous gneisses is interleaved with the amphibolites on Storø (Fig. 2). Near the structural base of the supracrustal sequence, grey compositionally layered felsic biotite-hornblende gneisses of intermediate composition are often seen. The layering is expressed by variable proportions of hornblende, biotite, quartz and plagioclase. Sphene, apatite and ilmenite are common accessory minerals while garnet is uncommon. The aluminous gneisses contain high and variable amounts of garnet, biotite, sillimanite and cordierite, and minor amounts of staurolite and tourmaline. These rocks are characterised by strong foliation combined with compositional layering ( $\mathrm{cm}$ - to $\mathrm{dm}$-scale) to lamination (mm-scale; Fig. 3A). Amongst these rocks, a garnet-biotite gneiss, a sillimanite-garnet-biotite gneiss and a cordierite-garnet-biotite gneiss can be mapped as lithological units. These gneisses are characterised by a rusty brownish weathering colour (Fig. 2) mainly due to the high content of biotite. Within the package of aluminous gneisses, a $c .1 \mathrm{~m}$ thick characteristic and mappable unit with a very high content of magnetite and garnet occurs (Fig. 1). A magnetite-free quartz-garnetite, consisting of up to $90 \%$ garnet is interlayered with the magnetite-bearing rocks. Where the degree of exposure is high and using the garnet-magnetite rock as a marker horizon, a tight to isoclinal fold pattern with repetition of the tectono-stratigraphic units can be identified in the biotite-garnet gneiss.

Within these aluminous gneisses, a unit dominated by quartzite occurs. The composition varies from pure quartzite (>90\% quartz) to a rock composed predominantly of quartz with feldspar, sillimanite and light green muscovite, and locally with minor fuchsite, biotite or garnet.

At the other end of the spectrum, ultramafic lenses (boudins) form a characteristic component in the supracrustal sequence. The size of the lenses varies from round pods tens of metres in diameter to elongate lenses hundreds of metres thick and up to $1 \mathrm{~km}$ long (Fig. 1). The modal composition of the ultramafic rocks varies substantially. In the cores of the major bodies the rock is mainly composed of olivine, pyroxene (both orthopyroxene and clinopyroxene) 
and amphibole (hornblende and tremolite). The margins of these bodies consist commonly of tremolite-phlogopite schist with variable chlorite and actinolite. This rock is locally affected by prograde breakdown of chlorite producing a conspicuous texture where large aggregates of parallel platy olivine crystals are intergrown with large chlorite crystals at high angles to the foliation (Fig. 3B). The ultramafic rocks are locally altered to serpentinite.

\section{Gold mineralisation}

Gold occurrences are located in the amphibolite-dominated parts of the supracrustal sequence. They are often found in zones where the amphibolite is enriched in biotite and garnet and often associated with pyrrhotite, arsenopyrite and loellingite $\left(\mathrm{FeAs}_{2}\right)$. Gold is found both in sericitised plagioclase and within garnet (Juul-Pedersen et al. in press), indicating that the gold mineralisation predates the metamorphic event at c. 2700-2630 Ma (Hollis 2005). The gold is also often associated with quartz veins, and in these visible gold is locally found.

\section{Geochemistry}

The amphibolites have a composition equivalent to tholeitic basalts and are interpreted as metamorphic equivalents of basalts. Based on their geochemistry, Polat (2005) stated that the amphibolites have a subduction zone geochemical signature. The common occurrence of calc-silicates is taken as a sign of hydrothermal alteration in a sea-floor environment (Polat et al. 2007). The grey biotite hornblende gneiss of intermediate composition could be the metamorphic equivalent of an intermediate volcanic rock. The ultramafic rocks have $\mathrm{MgO}$ in the range of 20 to $40 \mathrm{wt} \%$, high $\mathrm{Cr}$ and $\mathrm{Ni}$ (1500 to $4000 \mathrm{ppm}$ ) and $\mathrm{CaO} / \mathrm{Al}_{2} \mathrm{O}_{3}$ ratios around 1, suggesting a komatiitic protolith. The garnet-biotite gneiss, cordierite-garnet-biotite gneiss and sillimanite-garnet biotite gneiss are generally characterised by high $\mathrm{Al}$ contents consistent with a sediment protolith, which is supported by the observation of detrital zircon grains in these rocks (Hollis et al. 2006). The gneisses of supposed sedimentary origin have distinctly different $\mathrm{Zr} / \mathrm{TiO}_{2}$ ratios compared to the amphibolites (Fig. 4). There are, however, some extremely aluminous rocks (consisting primarily of garnet and sillimanite together with quartz, feldspar and biotite) in contact with the amphibolite on Qingaq, and these rocks have $\mathrm{Zr} / \mathrm{TiO}_{2}$ ratios similar to the amphibolites (Fig. 4). As neither $\mathrm{Zr}$ nor Ti is likely to be mobile in a non-alkaline environment they have probably been derived from basalt by sericitisation caused by hydrothermal alteration (cf. Garde et al. 2007 - this volume). This process can lead to volume loss due to loss of elements
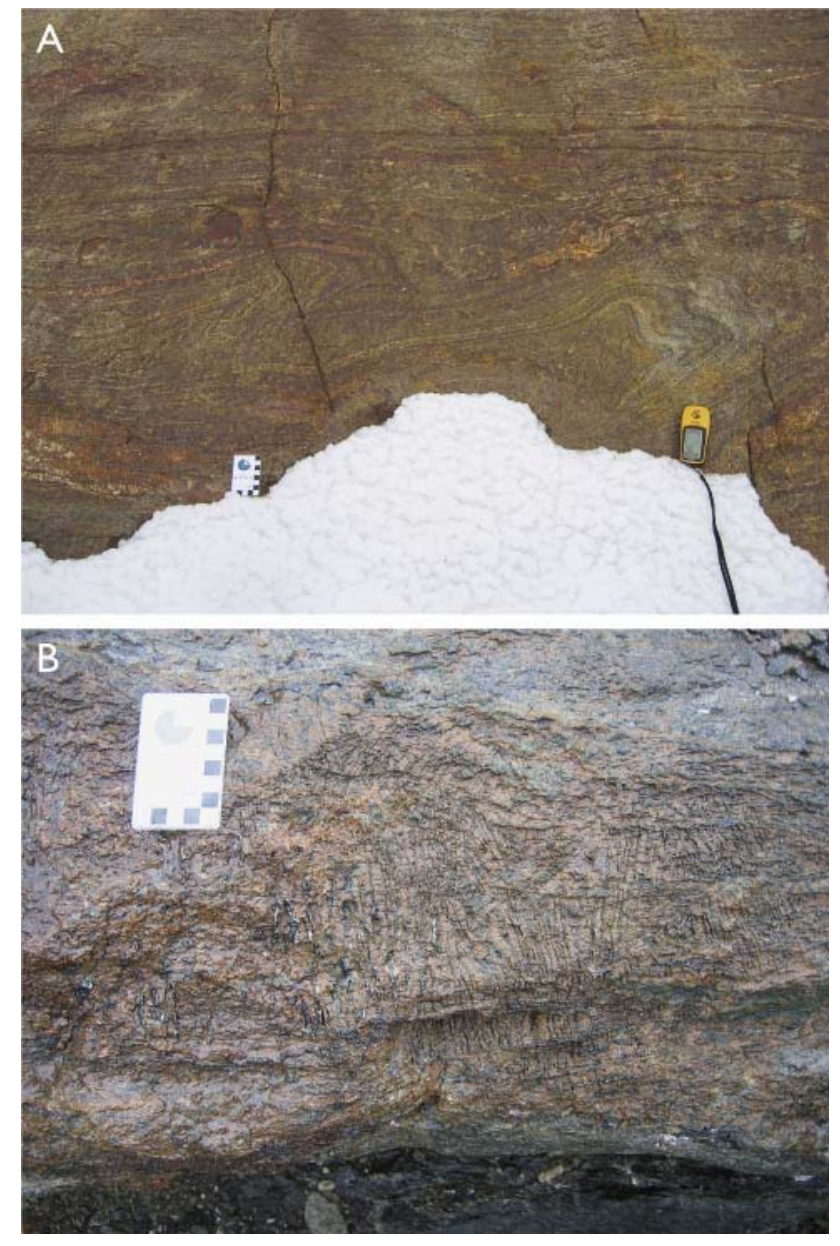

Fig. 3. Appearance of selected lithologies. A: Thinly laminated, rusty, garnet-sillimanite-biotite gneiss with tight to isoclinal folds. B: Ultramafic rock with a conspicuous texture consisting of sets of parallel oriented, up to $10 \mathrm{~cm}$ large, platy, olivine crystals together with large chlorite crystals.

such as $\mathrm{Ca}, \mathrm{Si}, \mathrm{Fe}$ and $\mathrm{Mg}$, and accordingly to increased concentrations of $\mathrm{Al}$, Ti and other immobile elements together with $\mathrm{K}$ (stable in the sericite). This rock type contains gold likely to have been introduced during the intense (premetamorphic) hydrothermal alteration. The more common goldbearing zones within the amphibolites are characterised by elevated contents of biotite and garnet. These rocks have increased concentrations of $\mathrm{Al}$ and $\mathrm{K}$ likely to have been caused by a similar process.

\section{Ages and structural relations}

Detrital zircon from a garnet-biotite-sillimanite-cordierite gneiss and from a quartzite has been analysed (Hollis 2005; Rink-Jørgensen 2006) using laser ablation techniques (cf. Frei et al. 2006). The results indicate that there are two distinct sources for these rocks (Fig. 5). The garnet-biotite-sillimanite-cordierite gneiss contains detrital zircon distributed 


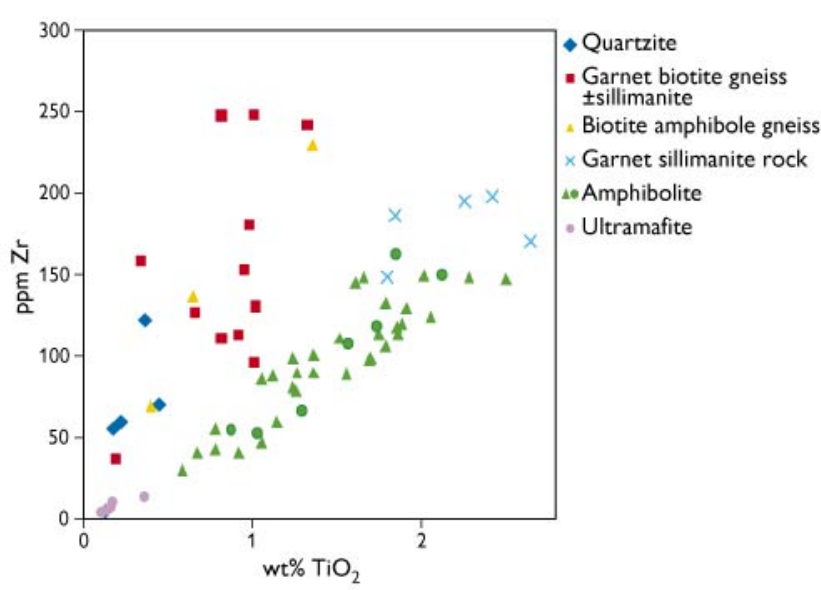

Fig. 4. Plot of $\mathrm{Zr}$ ppm vs. $\mathrm{TiO}_{2} \mathrm{wt} \%$ in different rock samples from Qingaq on Storø.

in two age populations around 2880 and $2830 \mathrm{Ma}$. We suggest that the rock had an immature sedimentary precursor, possibly derived from erosion of a relatively young volcanic arc formed in two episodes at 2880 and $2830 \mathrm{Ma}$. The detrital zircon in the quartzite, which is likely to represent a mature sediment, forms populations with main peaks around 2960 and $3010 \mathrm{Ma}$ and a minor peak at $3180 \mathrm{Ma}$. This rock must have had a distinctly different source and probably represents the erosional products of an older continent (e.g. the Nûk gneisses). This difference in sources is consistent with a model of formation of the supracrustal rocks in a back-arc environment. The immature sediments are likely to have been derived from the relatively young rocks in the arc, whereas the mature quartzites are likely to originate from the older rocks located on the continent side of the back-arc basin. This is supported both by the observation that the amphibolites formed in an arc environment and by the suite of rocks present. This environment is very similar to that envisaged for Canadian Neoarchaean supracrustal belts (Sandeman et al. 2006).

\section{References}

Frei, D., Hollis, J.A., Gerdes, A., Harlov, D., Karlsson, C., Vasquez, P., Franz, G. \& Knudsen, C. 2006: Advanced in situ geochronological and trace element microanalysis by laser ablation techniques. Geological Survey of Denmark and Greenland Bulletin 10, 25-28.

Friend, C.R.L. \& Nutman, A.P. 2005: New pieces to the Archaean terrane jigsaw puzzle in the Nuuk region, southern West Greenland: steps in transforming a simple insight into a complex regional tectonothermal model. Journal of the Geological Society (London) 162, 147-162.

Garde, A.A., Stendal, H. \& Stensgaard, B.M. 2007: Pre-metamorphic hydrothermal alteration with gold in a mid-Archaean island arc,

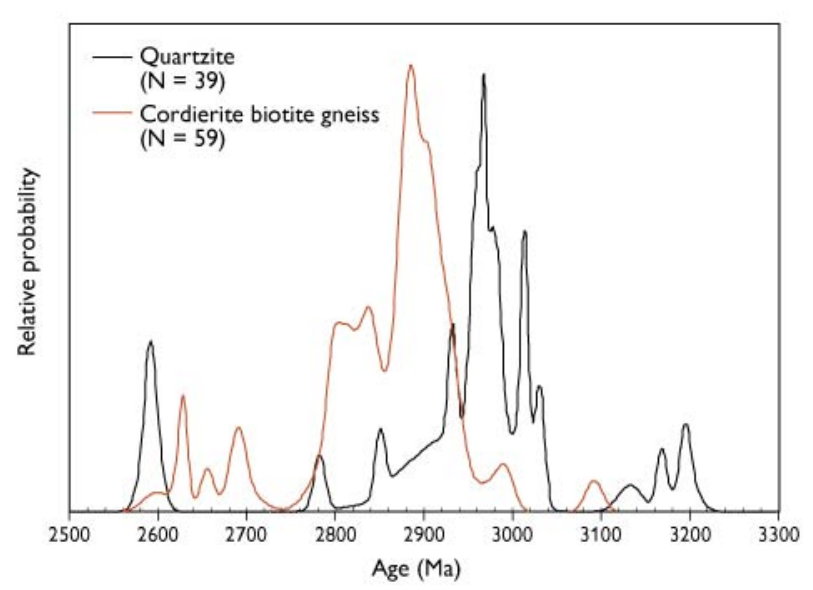

Fig. 5. Detrital zircon populations from two rock samples from Storø. Sample 481465 is a garnet-biotite-sillimanite-cordierite gneiss and 481283 is a quartzite.

Godthåbsfjord, West Greenland. Geological Survey of Denmark and Greenland Bulletin 13, 37-40.

Hollis, J.A. (ed.) 2005: Greenstone belts in the central Godthåbsfjord region, southern West Greenland: geochemistry, geochronology and petrography arising from 2004 fieldwork, and digital map data. Danmarks og Grønlands Geologiske Undersøgelse Rapport 2005/42, 215 pp.

Hollis, J.A., Frei, D., van Gool, J.A.M., Garde, A.A. \& Persson, M. 2006: Using zircon geochronology to resolve the Archaean geology of southern West Greenland. Geological Survey of Denmark and Greenland Bulletin 10, 49-52.

Juul-Pedersen, A., Frei, R., Appel, P.W.U., Persson, M. \& KonnerupMadsen, J. 2007: A shear zone related greenstone belt hosted gold mineralisation in the Archean of West Greenland. A petrographic and combined $\mathrm{Pb}-\mathrm{Pb}$ and $\mathrm{Rb}-\mathrm{Sr}$ geochronological study. Ore Geology Reviews 32, 20-36.

Nutman, A.P., Friend, C.R.L., Barker, S.L.L. \& McGregor, V.R. 2004: Inventory and assessment of Palaeoarchaean gneiss terranes and detrital zircons in southern West Greenland. Precambrian Research 135, 281-314.

Polat, A. 2005: Geochemical and petrographic characteristics of the Ivisartoq and Storø greenstone belts, southern West Greenland: progress report. Danmarks og Grønlands Geologiske Undersøgelse Rapport 2005/42, 80-112.

Polat, A., Appel, P.W.U., Frei, R., Pan, Y., Dilek, Y., Ordónez-Calderon, J.C., Fryer, B., Hollis, J.A. \& Raith, J.G. 2007: Field and geochemical characteristics of Mesoarchean ( $3075 \mathrm{Ma})$ Ivisartoq greenstone belt, southern West Greenland: evidence for seafloor hydrothermal alteration in supra-subduction oceanic crust. Gondwana Research 11, 69-91.

Rink-Jørgensen, M. 2006: In situ U-Pb datering af zirkoner i teori og praksis til bestemmelse af alder og populationer af detritale zirkoner, med anvendelse på en prøve fra Nuuk regionen i det sydlige Vestgrønland. Unpublished B.Sc. project, Københavns Universitet, Danmark.

Sandeman, H.A., Hanmer, S., Tella, S., Armitage, A.A., Davis, W.J. \& Ryan, J.J. 2006: Petrogenesis of Neoarchaean volcanic rocks of the MacQuoid supracrustal belt: a back-arc setting for the northwestern Hearne subdomain, western Churchill Province, Canada. Precambrian Research 144, 140-165.

\section{Authors' addresses}

C.K. \& J.A.M.v.G., Geological Survey of Denmark and Greenland, Øster Voldgade 10, DK-1350 Copenhagen K, Denmark. E-mail: ckn@geus.dk

C.Ø., NunaMinerals, Vandsøvej 5, P.O. Box 790, DK-3900 Nuuk, Greenland.

J.A.H., Northern Territories Geological Survey, P.O. Box 3000, Darwin NT 0801, Australia.

M.R.-J., M.P. E K.S., Institute of Geography and Geology, University of Copenhagen, Øster Voldgade 10, DK-1350 Copenhagen K, Denmark. 